\title{
15
}

\section{PETROLEUMSCAPE AS HERITAGE LANDSCAPE}

\section{The Case of the Dunkirk Port City Region}

\section{Carola Hein, Christine Stroobandt, and Stephan Hauser}

In 2009, Jean-Francois Vereecke, an economist with the Urbanism Agency of Flanders-Dunkirk (Agence d'urbanisme de la région Flandre-Dunkerque [AGUR]), developed the Toile Industrielle (Industrial Canvas ${ }^{\circledR}$ ), a visualization of the interindustrial network of Dunkirk, an industrial city in northern France (Figure 15.1). ${ }^{1}$ The illustration situated the economic network of Dunkirk in the context of international markets, subcontractors, and competing ports. The accompanying analysis revealed the economic impact of the proposed closure of the Total refinery, particularly on the port of Dunkirk. ${ }^{2}$ This helped local actors negotiate with the national government, which agreed to the construction of a liquefied natural gas (LNG) terminal in the city to strengthen the local industrial ecosystem. Furthermore, in 2016, when the Total refinery finally closed most of its activities in Dunkirk, the company kept part of the refinery running as a training center called "Oleum" - the first in Europe-therefore retaining some of the local oil-related knowledge in the city. ${ }^{3}$

While the Toile Industrielle visualizes the economic presence of oil in Dunkirk, it does not capture oil's spatial impact — inscribed in the pollution of its soils — or its impact on the narrative of the city. There is a need to further explore the physical reality of a place where the petroleum economy is coming (or must come) to an end and where the oil industry has vacated large sites, upsetting the long-standing economic, spatial, and social structure of the city. Since the 1860s, the life and death of petroleum sites in port cities have occurred with a lack of complete information regarding the places and dates where related activities took place. This legacy has left patches of pollution in port cities, knowledge about their existence is sometimes lost, and most of them have never been cleaned up. This chapter explores the petroleum history of Dunkirk and the importance of the role of port city regions in the establishment, continuity, and imaginary of the petroleumscape. It reveals the challenges involved in addressing the heritage embedded in former petroleum sites that have not been fully documented, even though they form part of the urban and social fabric and the imaginary of generations of inhabitants.

The history of Dunkirk is a prime example of how private and public oil interests have shaped port city regions for more than 150 years and have led to the population's dependence 


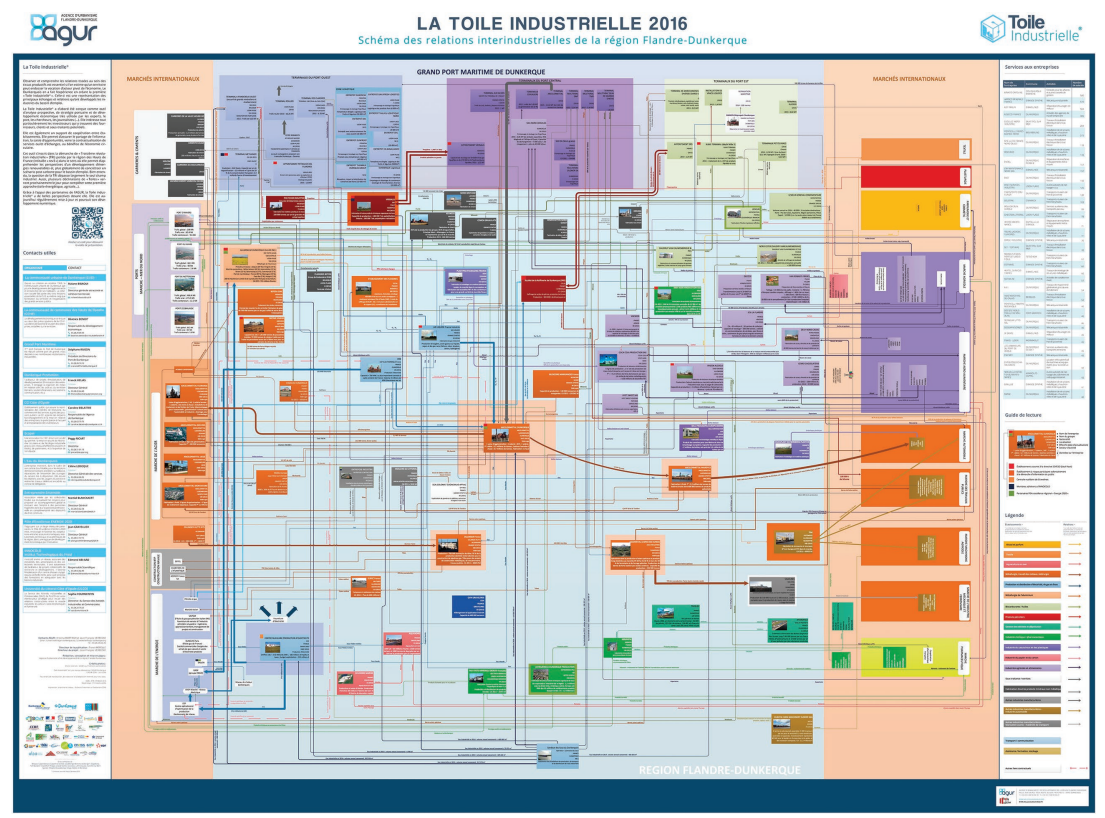

FIGURE 15.1 The Toile Industrielle in 2016. Source: Jean-François Vereecke. Source: https:// fr.wikipedia.org/wiki/Toile_industrielle\#/media/Fichier:AGUR_Toile_industrielle_ 2016.jpg

on petroleum as a provider of jobs and a creator of spaces. Global and local actors have built industrial sites-refineries, storage tanks, and port facilities-and other oil-related sites, such as administrative, housing, and leisure facilities throughout the city. Petroleum shaped the city and its structures remain, even if the petroleum has largely left. The closure of oil facilities, including the refinery, requires acknowledgment not only of the economic but also of the spatial impact of the end of the petroleumscape. ${ }^{4}$ With the refinery closing, Dunkirk has moved to the forefront in the development of post-oil economies and landscapes. Planning for the future of Dunkirk demonstrates the challenges and opportunities of transforming an area that has long been dedicated to the transshipment and refining of oil in line with new energy practices and the social and spatial conditions they require. The transformation is not limited to industrial spaces, as exemplified by the demolition of the Cité des Ingénieurs in 2018, a historic housing district for oil company employees designed by Max Wenders in 1931.

Through the lens of Dunkirk's spatial transformation, and particularly the impact of two major oil companies-BP and Total - on the city's spatial development, government, and culture, this chapter considers how various actors in Dunkirk's history have adapted to changing economic and spatial conditions. What kinds of oil spaces have they created and through which means? The chapter also analyzes recent design proposals for a postoil Dunkirk that were inspired by the concept of the petroleumscape. Understanding the long-term impact of oil on governance and the built environment in Dunkirk can help us prepare for the transformation of other (port) cities in northern Europe and around the world. 


\section{The Role of Ports in the Global Petroleumscape}

Petroleum is a natural product that was used sparingly for thousands of years as it bubbled out of the ground; it only gained its current ubiquity with industrial drilling, refining, and scientific innovations that increased the product's usability (see Hein, introduction to this volume). Throughout the nineteenth century, inventors, businessmen, and chemists worked to create an efficient lamp and to refine petroleum (replacing whale oil, which was expensive, and other oils that could be used as food). ${ }^{5}$ In the twentieth century, improvements in refining technology and chemistry provided the foundation for transforming petroleum into a rapidly increasing number of new products, including well-known ones, such as vinyl flooring, paint, and plastics, and also many that are less familiar, including petroleum-based fibers such as nylon, acrylic, or polyester as well as microplastics like microbeads used in toothpaste and skincare products. Oil companies, through their refineries, have provided an endless number of products to suit particular needs and interests.

With the rapid rise of petroleum consumption in places where few oil sources existed, places of oil extraction, refining, administration, and retail had to be connected around the world, including across seas. Producers located storage sites and refineries along the flows of oil. In the early years of petroleum production in Pennsylvania, Baku, and Gallicia- to name just a few early production sites - producers located refineries and storage sites close to extraction sites. It took several years for shipping and trading companies to find locations for storage and refining facilities that could handle the specific environmental and fire hazards of petroleum. ${ }^{6}$ Private entrepreneurs ran much of the business in the mid-nineteenth century, each controlling a part of the industry on their own land. Over time, local traders were pushed out of the market by a handful of transnational oil companies, including Exxon Mobil, BP, and Shell, which emerged in the late nineteenth century. As nation-states came to realize the importance of petroleum as a fuel, including for military purposes, they collaborated with petroleum companies in the discovery, extraction, and resale of petroleum. Over time, ports, cities and their regions began to thrive on the global petroleum trade as shipping linked diverse places of production and consumption around the world and as port cities emerged as transportation hubs and sites of petroleum refining.

Port cities were important as both export and import hubs. The industrial nations of Western Europe had only a small number of local petroleum sources and depended on imports. Port cities on the North Sea, including Dunkirk, Antwerp, Rotterdam, Hamburg, and Wilhelmshaven, became nodes in the oil distribution system, first for lighting oil, then for motor fuel, and later for oil used in manufacturing other products. The story of petroleum refineries in European ports really started in the 1860s, when small companies began to import petroleum from the US. The first barrels of oil were transported by sailing ships, arriving in ports that were equipped to store and transship a range of other, less dangerous, goods. Soon afterwards, companies built specialized storage sites and refineries along the northwest European coast to hold and process imported petroleum. As national entrance gates for petroleum flows from abroad-including from colonies or former colonies- port cities became an important asset for their respective governments. They served as access points of petroleum storage and refining, supplying crude and refined products to the hinterland, including the large inland capitals. As a country with limited petroleum within its borders and in its colonies, France, like the UK, became a big petroleum importer in the mid-nineteenth century and developed its own petroleum policy through the creation of the 
company Total. Dunkirk was one of the main hubs that kept petroleum flowing in France. Its urban form has been marked by oil transport and transformation, by the appearance and disappearance of petroleum sites, with its soil retaining a 150-year legacy of pollution.

\section{Dunkirk in the French Oil System}

Like most of Western Europe, Dunkirk's industrial petroleumscape was largely shaped by private business with political support by both local and national institutions. Occasionally, the same individuals represented private business and local or national institutions. Entrepreneurs were among the first to establish a petroleum refinery on the northwest European coast. In Dunkirk, a refinery may even have preceded the arrival of foreign petroleum. In 1861, the Raffinerie Trystram et Crujeot, in Petite-Synthe, opened along the canal of Mardyck (today part of Dunkirk). The first documented arrival of petroleum from Pennsylvania did not take place until $1863 .^{7}$ The early construction of the refinery may have given Dunkirk a head start in the petroleum business.

The further development of refineries was the result of political interventions. In 1863, the French government issued a tax decree-the first appearance of oil in the French customs tariff system ${ }^{8}$ - that put taxes on the import of refined products to ensure that the refining of petroleum took place on French soil. To avoid these taxes, oil companies opted to build refineries in France and erected the necessary infrastructures for its transport. In 1874, the Raffinerie Clère et Boilet opened in Coudekerque-Branche, south of Dunkirk, with a river connection to the harbor, and a few years later, the refinery received dedicated access to the newly built railway station (financed in large part by Clère). ${ }^{9}$ This refinery was also refining American crude oil, which it then sent via canal and railway to the hinterland, particularly to Paris.

This and other petroleum installations appeared in the city with little attention to their environmental impact or the fire hazard they posed (Figure 15.2). The refinery in Coudekerque-Branche burned down in 1888 and again in 1891, the second event receiving much media attention, and perhaps even a third time. ${ }^{10}$ Nonetheless, the facility was again rebuilt on the same site and only closed in 1906. But refineries are rarely replaced once established. Without a strong incentive, it is more efficient for companies to keep an old site and benefit from the existing infrastructural and economic networks than to demolish a retired refinery. Because refineries are tied to a specific physical location and local infrastructure, they are hard to move; and because they are hard to move, in time they become even more tightly linked to their location. As the international professional services company Ernst and Young put it: "Old refineries rarely die.".11

Starting in the nineteenth century, economic and political interests surrounding oil were closely connected. A number of petroleum companies emerged in France after the 1850s; they would go on to become the core of the French petroleum trade and their owners would wield significant political power. Edmond Paix established his refinery in 1863 in Saint-Amand near Douai; Henri Desmarais set up shop in 1878 in Le Havre; Alexander Deutsch (de la Meurthe) established his first industrial oil facility in 1862 in Pantin; and Fenaille, Châtillon et Despeaux began its petroleum refining in 1868 in Aubervilliers. Desmarais frères, Deutsch de la Meurthe, and Fenaille et Despeaux alone refined about 90 percent of French oil imports in 1895. Seven other companies started importing after 1895: G. Lesieur et fils, Compagnie générale des pétroles, Compagnie Industielle des pétroles, 


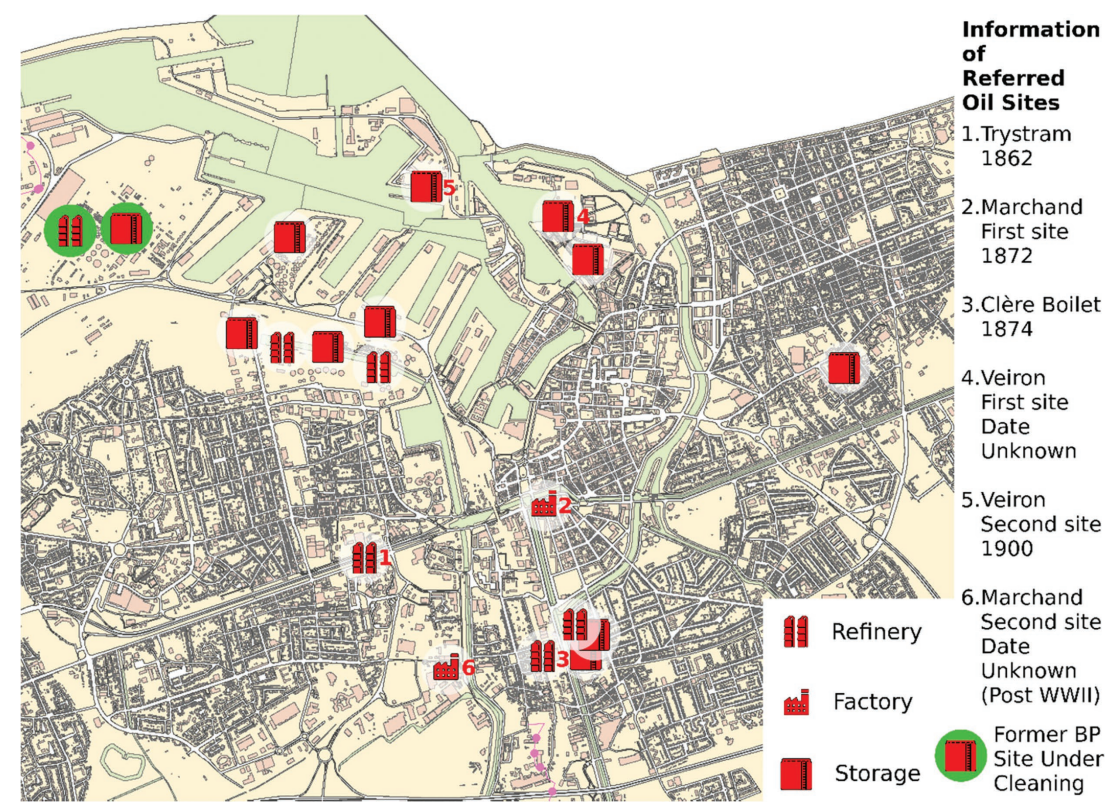

FIGURE 15.2 Oil-related sites (refineries, storage sites, and factories in Dunkirk). Map by Stephan Hauser, based on recent geographic information about the city provided by the Learning Center of Dunkirk.

Raffinerie du Midi, Société Lille-Bonnières-Colombes, Raffinerie de pétrole du Nord, and Paix et Cie. ${ }^{12}$ All these companies, which became known as the Cartel of Ten, bought petroleum from Standard Oil of New Jersey (Rockefeller), giving the American company lobbying power with the French state. In 1903, the Parliament (Chambre des Députés) pushed the government to propose a law giving the French state a monopoly over the refining of petroleum. ${ }^{13}$ As the French government imposed taxes on the import of refined products in 1863, refining in France became more lucrative. In 1903, the government introduced another tax, this time on crude imports reaching French refineries, to balance what it considered an excessive profit from refining petroleum companies. ${ }^{14}$ Taken up again in 1909, the new taxation project remained without effect as Standard Oil threatened to cease oil deliveries if its economic interests were challenged-at least according to right-wing sources. ${ }^{15}$ Already in the days of lighting oil, before cars became major petroleum consumers, the predecessor of Exxon Mobil had gained enough global power to sway national politics and decision-making.

Other private companies connected to national projects formed in those years would similarly lay claim to entire parts of the globe, strategically deploying their national hinterland or colonial reach as well as the political and economic alliances of their owners. The Russian connection, for example, was strong in Dunkirk. In 1891, on Dock 4 of the Dunkirk port, the André oil company built storage for mineral oils arriving from Baku in Azerbaijian and from Batumi in Georgia on the Black Sea, selling them for Branobel, run by brothers Robert and Ludvig Nobel (whose brother Alfred Nobel founded the Nobel Prize). Branobel collaborated with Shell and with Mazout (a daughter company of Bnito owned 
by the Rothschild family) to keep Standard Oil, an American company, out of the Russian markets. In 1912, the company G. M. Lianozov Sons (also known as G. M. Lianosoff Fils), the third-largest financial and industrial group in Russia, administered by Stepan Lianozov (or Lianosoff) — called the Russian Rockefeller-joined the Russian General Oil Corporation, a group of over twenty investment banks and French, Russian, and Belgian funds as well as Russian oil industry leaders.

The new oil industry reshaped the industrial petroleumscape in port cities throughout Europe and beyond as oil storage and refining territories expanded. In 1912, Lianosoff opened an industrial site in France's St. Pol s/Mer for storing and packaging Russian lubricants and other oil products that it then transported elsewhere. The same year, he founded the company of G. M. Lianozov Sons with branches in London, Antwerp, and Paris. ${ }^{16}$ These branches served as entrance points for the development of European sales of oil in competition with the Nobel and Rothschild companies until 1916, when Emmanuel Nobel, Ludvig Nobel's eldest son, took over G. M. Lianozov. After the 1917 Russian Revolution cut off the Nobel procurements, the André Company started importing oil from the US and the Dutch Indies. In 1920, Branobel was nationalized, but the Nobels managed to sell 50 percent of their stock to the Standard Oil Company of New Jersey. Together, Lianozov and Emmanuel Nobel participated in anti-Bolshevik activities with Russian immigrants in Paris in 1920 (they were trying to defend their ownership of extraction and production sites). ${ }^{17}$ Private petroleum actors had become unable to efficiently push the government to protect their interests.

With the emergence of the car and other vehicles with oil-burning engines (including ships) and increasing petroleum consumption in the early 1900s, energy consumption in Europe increased. The major American, Russian, English, and Dutch companies started to compete for access to European markets, and thus for land and influence in the main port cities. Some local companies expanded, and petroleum-related industries formed new organizational clusters. By 1908, Georges Lesieur had separated from Desmarais and took over the Dunkirk Oil Refinery in exchange for land ceded to the previous owners: Fenaille and Despeaux, Paix, Desmarais, Deutsch, who had established the Raffinerie de Pétrole de Dunkerque in 1896. ${ }^{18}$ In 1909, Dunkirk's Chamber of Commerce granted permission for a pipeline to bring refined oil from Dock 4 in Dunkirk to a petroleum refinery (Raffinerie de Dunkerque [ex-Trystram]) and warehouse in Petite-Synthe and to build storage. ${ }^{19}$ Many of petroleum's dangers were known but mostly ignored by decision-makers.

While the early years of petroleum were characterized by private entrepreneurs, the business of oil developed quickly into a matter of national security for countries around the world, including France. Petroleum extraction in colonies was key to the development of many European countries. World War I made it clear that national dependence on foreign products was not a long-term option, and within a few years a French national company would emerge. ${ }^{20}$ In the 1920 s, the French state took control of oil importing and took over former German installations in the Middle East. The role of port cities as nodes in the transportation and refining of petroleum became even more important. Between 1920 and 1930, another seven industrial petroleum sites opened, inserting Dunkirk and other French ports into larger petroleum networks. Georges Lesieur - a partner in the Cartel of Ten-and Paix established the Compagnie Occidentale des Produits du Pétrole (COPP), built storage in the Dunkirk port, and developed the Courchelettes refinery to refine petroleum from Abadan, a refinery and oil city in southern Iran. ${ }^{21}$ In 1920 and 1921, Paix-Lesieur ${ }^{22}$ signed an agreement with the Anglo Persian (later Iranian) Oil Company (APOC; a predecessor to BP). 
Then, in 1920, five more entities-APOC, SNO (Société Navale de l'Ouest), La Banque de la Seine, and Sir Basil Zaharoff-established a refining company with headquarters in Paris, the Société Générale des Huiles de Pétrole (SGHP), and relaunched the activities of the Courchelettes refinery. ${ }^{23}$ The refineries in Dunkirk were thus within national control and firmly embedded in international petroleum flows.

The city government of Dunkirk began to promote its growing role as distribution and production center. At the time, the infrastructure of oil was a celebrated part of the public imaginary and perceived as a sign of economic growth. The Chamber of Commerce in Dunkirk found the changes brought by oil so important that it commissioned Hugo d'Alesi to document them in a monumental painting for the World Exhibition in Paris (Figure 15.3). The painting shows Dunkirk from the waterside with the various docks and storage facilities. In the front, to the right of the entrance channel, the petroleum port was closed off by a floating barrier when a petroleum ship was in port. Another monumental painting made between 1923 and 1930 appears to have been inspired even more strongly by the pride in oil storage and handling. Viewing the scene from the sea, this anonymous painting again puts port activity at center stage (Figure 15.4). Former fortifications had been transformed into a green belt that appears ready to be populated with (industrial) activities: multiple oil storage tanks visible on both sides of the river give a vision of the port's industrial future after World War I. The painting shows the tanks lit by the sun, and the new structures are gleaming white in the front right of the image. This imagined future would come almost immediately to Dunkirk with the installation of large new refineries and storage sites. Dunkirk's Chamber of Commerce may have commissioned the painting; they displayed it at industrial and commercial exhibitions in France. Petroleum promised a better life and was not yet seen as an environmental threat or a cause of war.

France was keen on controlling petroleum for national purposes, and the ports played an important role in plans to achieve this goal. In order to make France less dependent on foreign petroleum companies, in 1924, French Prime Minister Raymond Poincaré created the Compagnie Française des Pétroles (CFP), the first national oil company, a predecessor

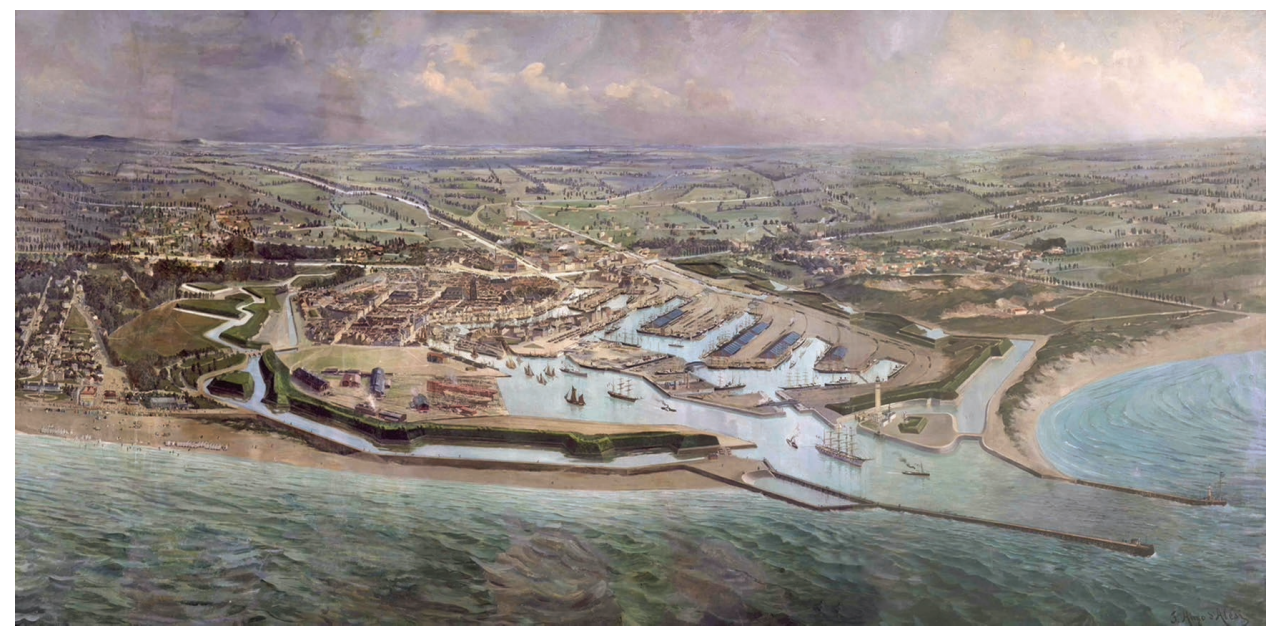

FIGURE 15.3 Panorama of Dunkirk port around 1900, painted by Hugo d'Alesi. Collection Musée portuaire Dunkerque. Cliché Studio Mallevaey. 


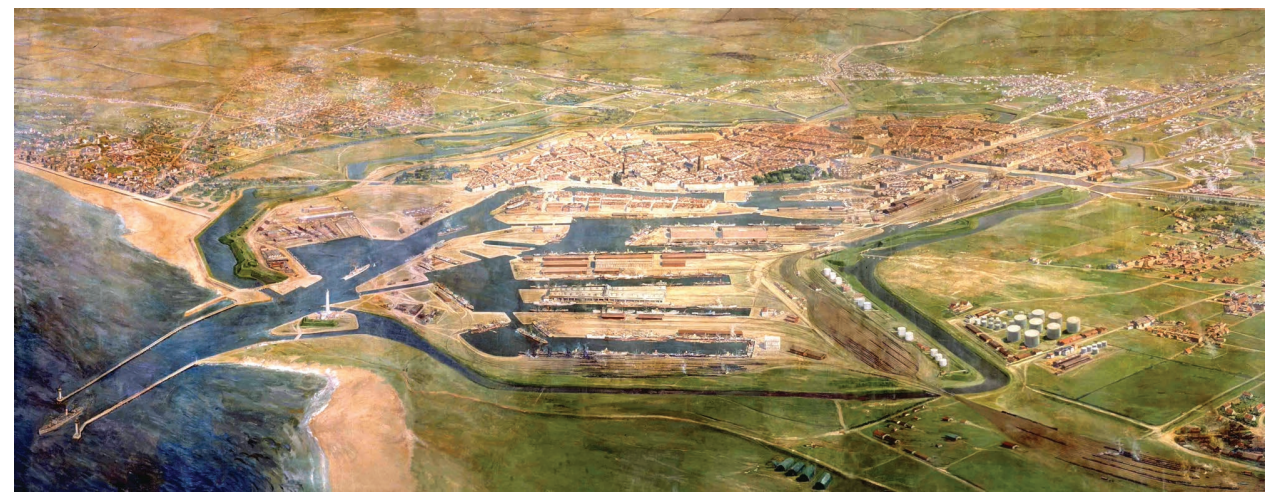

FIGURE 15.4 View of the City of Dunkirk around 1923. Collection of the Port Museum of Dunkirk.

of Total. Before World War II, France and Italy were the only countries that encouraged companies to site refineries within their territories so that they no longer depended on foreign deliveries of refined products. ${ }^{24}$ This company opened up new markets and sources (including in France), and started to import crude oil from Mesopotamia and Venezuela. The new oil company chose to route the oil to Paris by way of Le Havre and Marseilles. ${ }^{25}$ In Dunkirk, foreign countries, including the UK, had a major stake in the oil business. Foreign and French companies collaborated to buy up existing petroleum sites in Dunkirk to process their foreign-purchased crude oil. In 1920 and 1921, the future BP (then AngloIranian Oil Company through the French company SGHP) took control of the refineries in Dunkirk (Lesieur) and Courchelettes (Paix Cie) and their depots (Cie Occidentale des Produits Pétroliers). In 1929, the French state and investors (including Desmarais frères and Lille Bonnières et Colombes et ses filiales) helped establish the refining company CFR (Compagnie Française de Raffinage). ${ }^{26}$ PétroFina France then built the new Raffinerie de Pétrole du Nord in Dunkirk in 1932, on the site of what would become the BP refinery. ${ }^{27}$ All these intricate economic maneuvers ultimately had an impact on the spatial development of Dunkirk, on the industrial, infrastructural, or ancillary spaces of the local petroleumscape.

Like in many other port cities, petroleum sites in Dunkirk have been the target of military action, but they have also been rapidly rebuilt. In May of 1940, the refinery in Dunkirk was bombed and dismantled by the Germans. By the end of World War II, PetroFina lacked funding to rebuild and struck an agreement with SGHP-BP, the French arm of BP, in exchange for petroleum delivery, at a time when companies were hungry for access to crude oil. In 1947, the Monnet Plan (1947-1953) aimed at modernizing and developing basic and strategic industries (energy, steel, transport) as a way of relaunching economic activity and taking advantage of the Marshall Plan, which allowed SGHP-BP to rebuild the refinery in Dunkirk in the location occupied by the Raffinerie de Pétrole du Nord (and later Purfina) before the war. In 1948, the SGHP-BP started to build the new refinery on the western side of the port of Dunkirk in the area of Saint-Pol-sur Mer. ${ }^{28}$ In 1950, the refinery at Courchelettes was dismantled and moved to Dunkirk with a capacity of 350,000 tons per year. At the end of 1951, the first part of the refinery was built; in 1952, the refinery was completed and began operating. ${ }^{29}$ In agreement with the French government, British 
Petroleum PLC rebuilt and expanded the site of the former Raffinerie de Pétrole du Nord, which took the name of SGHP-BP in 1952, SF-BP in 1954, and later became BP.

The presence of the foreign petroleum companies in Dunkirk extended from the industrial petroleumscape to ancillary elements. The BP refinery, described by the French writer André Maurois as "the factory on the dunes," is an important part of the history of Dunkirk and exemplifies the economic strength of the region and the nation. ${ }^{30}$ In the 1950s, BP added storage of 500,000 $\mathrm{m}^{3}$ capacity and transported oil by rail, tank truck, and through the canals to the hinterland. ${ }^{31}$ To facilitate oil production in the war-destroyed city of Dunkirk, SGHP-BP needed housing for its employees. The company rebuilt the housing known as the "Cité des Ingénieurs," which was located next to the refinery (Figure 15.5). The neighborhood consisted of twenty-three houses with accommodations for the refinery's director, engineers, and foremen. With the housing development and its park-like setting, the company expressed both the early twentieth-century garden city concept and the 1930s modernist idea of connecting places of working and living. There was also a so-called "Cercle," a place for parties that also served as a restaurant. Public spaces were provided where families could meet and children could play.

The Cité des Ingénieurs exemplifies the way petroleum was perceived as an agent of welfare and a better life. In addition to the Cité des Ingénieurs, additional housing was needed for workers. The Cité Bayard in Saint-Pol-sur-Mer consisted of 160 houses and 333 apartments $2 \mathrm{~km}$ from the refinery. The BP also built twelve apartments in Rosendaël. Furthermore, the BP helped employees to build houses in Petite-Synthe, in an attempt to demonstrate that the company cared about the welfare of its employees. ${ }^{28}$ The lack of equipment and available houses pushed employees to also build their own homes. This movement of collaborative auto-construction called Castors was supported by funds from the refinery in the city of Dunkirk. Eventually, 200 houses were constructed.

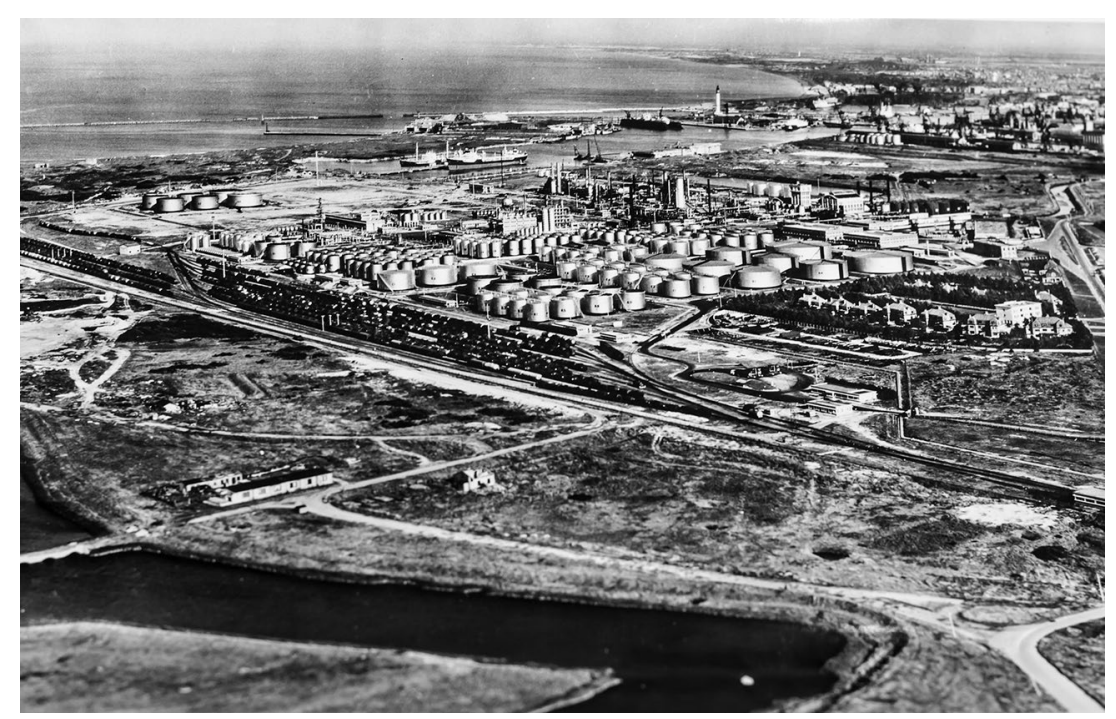

FIGURE 15.5 Raffinerie de Pétrole de Dunkerque, 1955. Archives de Dunkerque CMUA, 14FI63, copyright Lapie. 
Even in the early postwar period, petroleum appeared to companies, workers, and citizens alike as a unique opportunity rather than an environmental challenge. It would take several decades for the environmental and health hazards of the emerging technology to become evident. In the 1930s, when the Cité des Ingénieurs was built next to the refinery, it was considered a desirable place to live. Equipped with all the modern comfort available, the houses were, however, within the industrial territory of the port of Dunkirk. In the 1970s, the Cité des Ingénieurs began to empty, especially after the construction of the steel site USINOR, less than a kilometer away. The 1976 chemical incident of Seveso, in Italy, triggered a European classification of dangerous industries, with distance required between industry sites and residences. Refining sites were included in the dangerous classification and became subject to the distance requirement. In addition to the risk of accidents, everyday life for the inhabitants of the Cité des Ingénieurs included noise, odor, and pollution. Incidents occurred regularly in the refinery and the increasing pollution pushed the residents to leave. By 1995, it was a decaying neighborhood in the industrial port, deserted and walled. Instead of relocating the petroleum industry sites, it was the residents who had to move.

\section{Extension of the Port to Anchor the Petroleumscape}

The port and region of Dunkirk, like many other port city regions, thrived on petroleum into the late twentieth century. Accommodating it led local development. The refining activity in Dunkirk attracted the Pechiney aluminum industry, and the establishment of the USINOR steel industry in 1963 indicated the French government's commitment to create a coherent policy for the management of ports of national interest. In 1965, a law made ports autonomous - rather than controlled by the French state-as public institutions with financial autonomy. ${ }^{32}$ In 1966, the Port Authority of Dunkirk was established to improve the efficiency of the port and facilitate the settlements of economic actors. By the end of the 1960s, the port of Dunkirk was the third-most important French port in terms of trade-the major items being steel, petroleum, and textiles. ${ }^{33}$ Through the inclusion of local actors in the decision-making of the port authority, extensions and management of the port received additional support. As local authorities gained voices in port's strategy, more and more industries settled in Dunkirk and the expanding port redefined the industrial landscape of the city. The increase in shipping traffic and the size of ships in these years entailed significant changes, including moving the port away from the city. Deeper water allowed the berthing of container ships and oil tankers of 200,000 tons. The oil trade, which increased after 1972, when imports from North Sea exploration rose to a level similar to those from the Middle East, needed more space and deeper water. ${ }^{34}$ The BP refinery, then the only one in operation in Dunkirk, and the refineries in other parts of France were not able to satisfy domestic demand, so imports of refined oil from the Netherlands, Belgium, and Great Britain increased considerably. ${ }^{35}$

The oil economy and its industries remained strong in the 1970s. In 1974, the French oil company Total opened the new Flanders refinery in the municipality of Mardyck, the industrial port area of Dunkirk, close to existing heavy steel and metallurgical and petrochemical industries (including Copenor from Qatar). The new refinery, the last to be built in France, then occupied 230 ha and was located east of the port of Gravelines, along the grand canal Dunkirk-Denain. Pipelines connect it to the Flanders jetty, built in 1975 in the 
new western outer port, $8 \mathrm{~km}$ from Gravelines. The latter allows the berthing of oil tankers of 300,000 tons. Seeing its market share decline, the authorities of the BP refinery located in the older part of the industrial port with limited access capacity to 33,000 tons ships, abandoned the manufacture of fuels, and in 1981, turned to the production of lubricants. As early as 1976, it had benefited from the possibility of installing new storage tanks next to those of the Raffinerie des Flandres and using pipelines to connect the tanks to its production site. ${ }^{36}$ With such adjustments, until the 1980s, the oil industry in Dunkirk was able to continue making a positive impact on the urban economy and provided good housing, leaving an image that today many locals recall fondly.

In the 1980s, the tide turned for the oil industry and its unchecked growth came to an end. The 1979 oil crisis and the increasing price of oil had a strong impact on the rivalry between BP and Total. BP finally ended its oil refining operations in 1982 and dedicated its refinery exclusively to the refining of lubricants, waxes, and bitumen. In 2010, the refineries of Flanders (Dunkirk), Reichstett, Berre, and Petit-Couronne began to close, leaving behind all at once large sites to clean and transform in cities and leading to an abandonment of the old housing complex (Figure 15.6). The commercial activities of Total's refinery ceased in 2016, but the oil industry in Dunkirk still has an impact on the area through the refinery training center under the name Oleum. ${ }^{37}$ Together with Le Havre and Marseille, Dunkirk is the only port in France that can accommodate the largest container ships and large oil tankers. This is one of the reasons why the port authority intends to continue using the port as a hub for oil and gas transport. ${ }^{38}$

Today, the former Cité des Ingénieurs is a polluted and abandoned brownfield site in Dunkirk, exemplifying the relationships between global and local players and the impact of

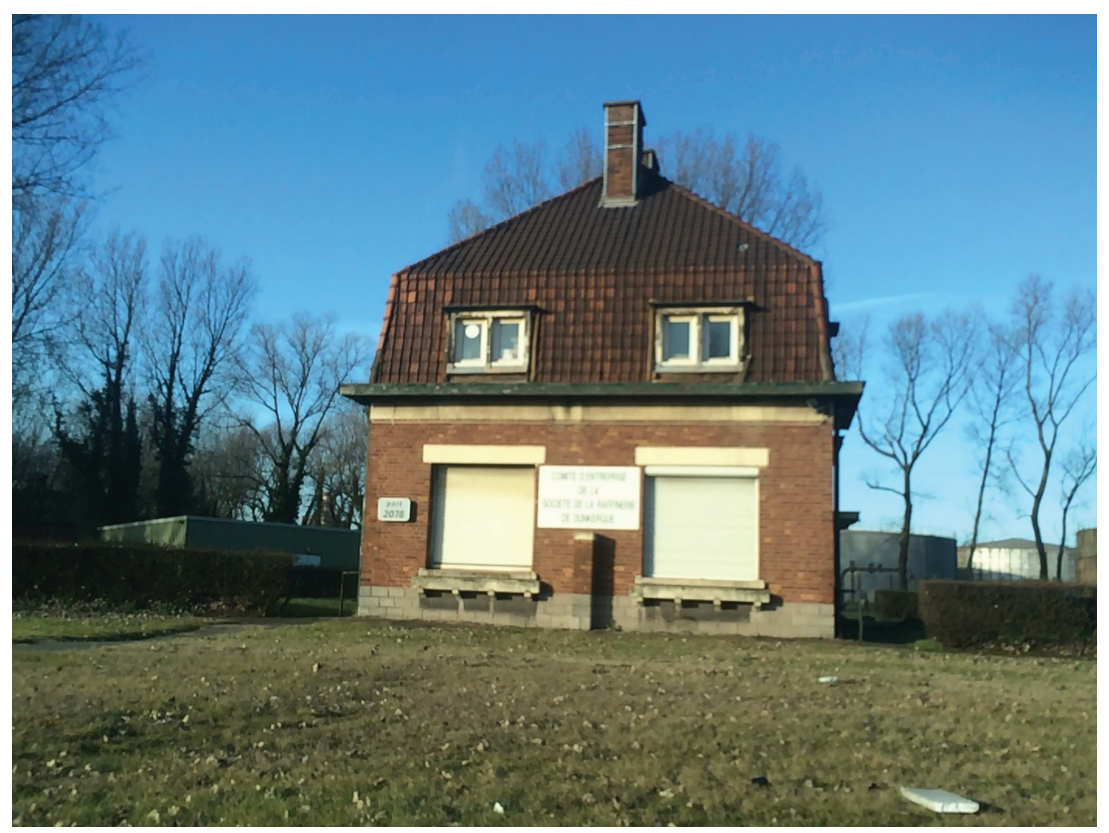

FIGURE 15.6 Abandoned building of the Comité d'Entreprise of the Société de la Raffinerie de Dunkerque. Source: Carola Hein. 
overcapacity in the petroleum sector on local urban development. ${ }^{39}$ It raises the question of how to reshape the spatial petroleumscape, the growth of which has shaped cities for some 150 years, and what message to send to future citizens about the oil heritage, which is an important part of the represented petroleumscape. In addition to providing educational training sites for the education of oil workers, Dunkirk now contains an experimental area for biofuels. Some sites are being dismantled and decontaminated and plans are being considered for an asphalt warehouse. Dunkirk now faces the challenge of reinventing itself by repairing and recycling its port, its port industries, its port heritage buildings, and the abandoned and unused areas between the port and the city. There are also opportunities to provide examples of experiments with transitions in energy, technology, and society and their spatial impact. All stakeholders, public and private, professional and lay, have an opportunity to consider the issues of the future of former oil-based industrial cities. ${ }^{40}$

With the support of the metropolitan area of Dunkirk, the Hauts-de-France region, and European funds and programs, several actors have begun urban and architectural renewal. Since 2010, the Port Authority of Dunkirk has implemented a comprehensive strategy for protecting its natural heritage, a Natural Heritage Master Plan (Schéma Directeur du Patrimoine Naturel [SDPN]). ${ }^{41}$ This tool has given rise to a series of initiatives to conserve and enhance nature within the port, such as one developing the former St Georges rail line between Bourbourg and Gravelines as an eco-landscape corridor. In addition, the port authority has opened the port to the city through visits, projects, and activities in schools. In addition, several actors aim to connect port and city. The Learning Center Halle aux Sucres educates the local community on issues of sustainability. A new Port Center aims to communicate with the citizens and to encourage collaboration between the port authority, the city of Dunkirk, and the port museum. These activities made Dunkirk one of the five finalists for the European Sea Port Organization Award in 2016 with the theme "Nature in Ports," for ports preserving natural heritage and connecting ports with the public. ${ }^{42}$

\section{Spatial and Social Development Beyond Oil}

In France and elsewhere, port cities like Dunkirk were shaped by global industry and national interests. The end of refining spells uncertainty for the future of flows through the port and for the landscape. Since the refinery ceased its commercial activities in 2016, the petroleum areas have become places for the development of new projects, visions, and practices. One important concern is that the oil industry not only affected the spatial planning of the area but also polluted the soil. Industry locations were often not recorded, and the short lifespan of many facilities presents problems for both authorities and citizens. ${ }^{43}$ Successive public authorities transformed these former industrial landscapes into urban areas, now with schools, housing, and parks. Many abandoned or transformed sites may still contain invisible pollution in the soil. This is a potential environmental and health catastrophe. Regular incidents around these industrial sites impacted air quality and are still affecting residents with potential limitations on planting vegetable gardens and use of surface water. In the case of Dunkirk, most of these sites are also in flood zones, which increase the risk of pollution spreading to a wider area. These soils need to be identified, studied, and the hazards addressed to avoid endangering the health of the inhabitants and users-and to fully address the heritage of oil. The narrative of the petroleum heritage of Dunkirk in all 
its facets-positive and negative-needs to be carefully studied and discussed as part of the green energy transition.

The Learning Center's activities are examples of efforts to educate citizens on the impact of oil on the built environment and the challenges and opportunities of overcoming petroleum dependency. Exhibits have included "Or Noir" (October 2018 to June 2019), which explored spatial approaches for Dunkirk beyond oil. ${ }^{44}$ Developed by students from Delft University of Technology, it considered the future of post-oil cities, focusing on Dunkirk and its mix of hazardous industries, refineries, huge steel plants, petroleum tanks, and other industrial structures. Students developed approaches and methods based on an analytical reading of maps, historical documents, and materials from the archives in Dunkirk. They then translated their research into individual approaches, and created visual representations of their findings as well as new projects for the future of the former refinery sites. ${ }^{45}$ Students considered the cultural meanings of oil in a post-oil world and how to provide opportunities for future generations without relying heavily on oil or other fossil fuels. What does post-oil mean? With this question in mind, they reflected on how to reshape the relationships between global and local, private and public, economy and ecology, people and nature, new and old cultures, energy and infrastructure, land and sea.

The students have explored energy narratives, examined the political and economic drivers of the transition, developed alternative infrastructure and food systems, proposed new construction materials and systems, and studied ways to turn polluted industrial sites into educational tools and creatively designed spaces for people and nature. They devised possible developments that tie in with the history of the sites while also giving the sites a completely new future, one that makes industrial spaces of oil available for new practices, that uses historical narratives to pave the way for postindustrial futures, and that relegates petroleum to a non-nostalgic past. Some of the students worked on how to reclaim polluted soil, others on how to realize new kinds of industries in the industrial area of the port and nearby urban districts, how to reuse oil industries in a creative way, or on redesigning entire pieces of coastline and finding new narratives and cultural values to once again link the port with the city.

Rashid Ayoubi provided perhaps the most critical and dystopian project. He imagined a past where four "companies"-Oil Arch, GreenLeaf, Every Drop Matters, MADInc.created a giant mountain over an abandoned refinery to produce the last drops of oil (Figure 15.7). While the refinery satisfies the society's needs for petroleum as a component in medicine, this hidden back end serves the people of Dunkirk, who use the global container trade and additional green energies to devote themselves to consumption and play.

Transition strategies were key to several projects. For more than 150 years, the petroleum industry has polluted water, soil, and air around its installations. Toxic material has seeped deeply into the ground. Clean-up, when not ignored, is often left partly or totally to local public partners. New approaches, technologies, and practices can help make clean-up a process that generates money, promotes innovation, and responds to collective needs. Ege Cakir proposed large autonomous "animals" that will roam the site of the Total refinery to clean up the soil and turn the remediated landscape into a recreational park. Select oil structures - refinery elements and storage tanks - remain as sculptures, a reminder of the industrial petroleumscape in its heyday and its negative impact on the environment and health.

Other students engaged concretely with new production and consumption patterns postoil. Gemma Galeno suggested using materials with low amounts of embodied energy that 


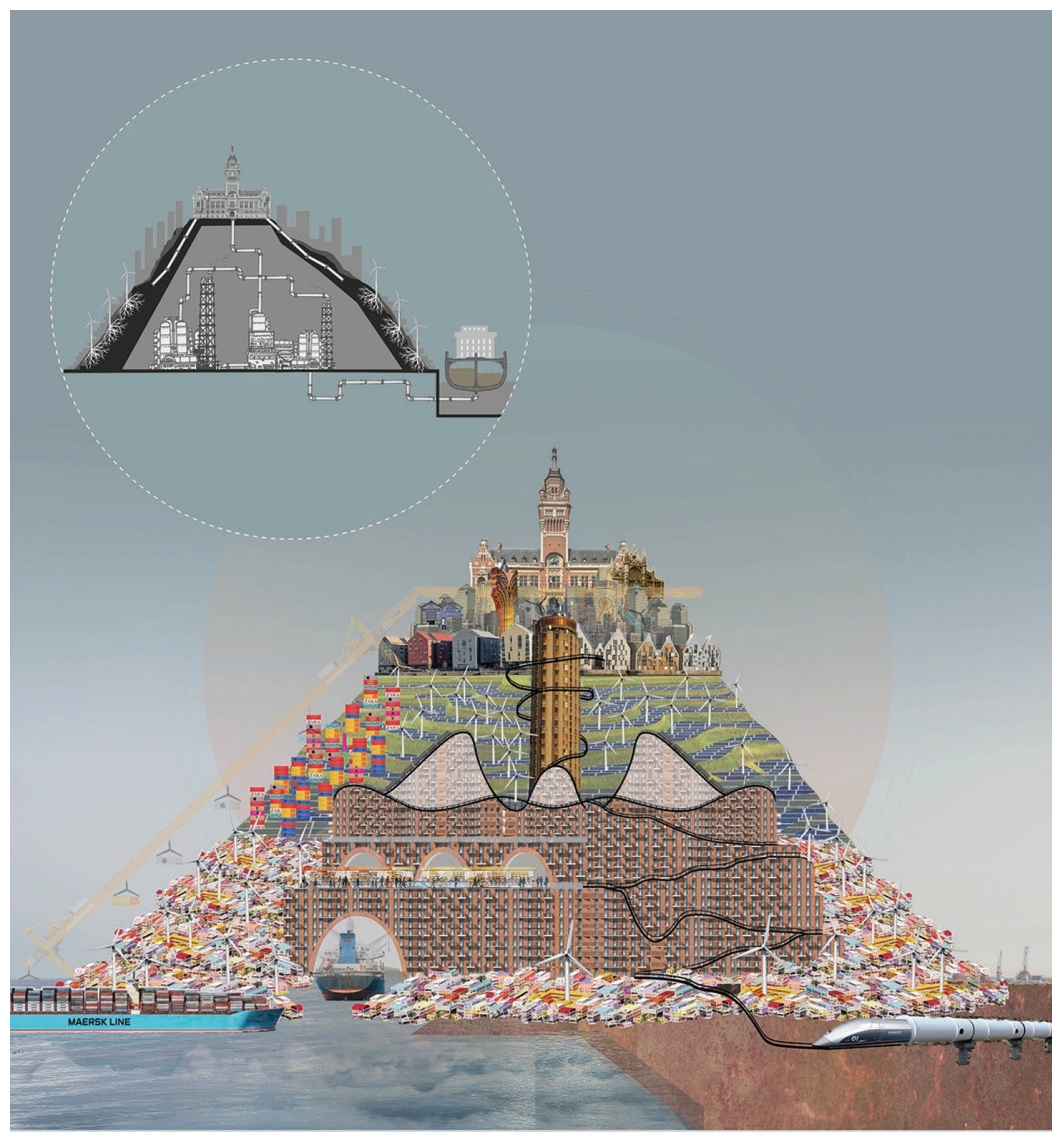

FIGURE 15.7 Rashid Ayoubi's dystopian vision of post-oil Dunkirk, Beyond Oil Studio Spring 2018.

are fabricated without the use of oil and do not contain oil (Figure 15.8). She proposed a new joint system for bamboo, a bamboo plantation, and a bamboo research center high-rise for Dunkirk. These projects represent just a few possible future developments and are early attempts at conceptualizing the impact of transitions involving energy, technology, and ways of life on our future built environment. Understanding the possible impact of new materials and new technologies as well as of new lifestyles and new utopian (and dystopian) narratives can help nurture a necessary conversation about a future beyond oil.

New actors and actor constellations are needed to transform the petroleumscape into a post-oil landscape. It is now up to the local population, policy makers and new industries to find and support a sustainable and meaningful use of areas facing a major change in the wake of new industrial energy landscapes. They require political action and legal tools to overcome the spatial, economic, and social legacies of oil. This process will need to involve a complete rethinking of the current cultural and economic model and it will require commitment by the government, private sector, and local community. ${ }^{46}$ Dunkirk's Toile Industrielle is an important instrument to measure economic flows; now, it is time to also map the spatial impact of petroleum over time and to confront its heritage-partly undocumented 


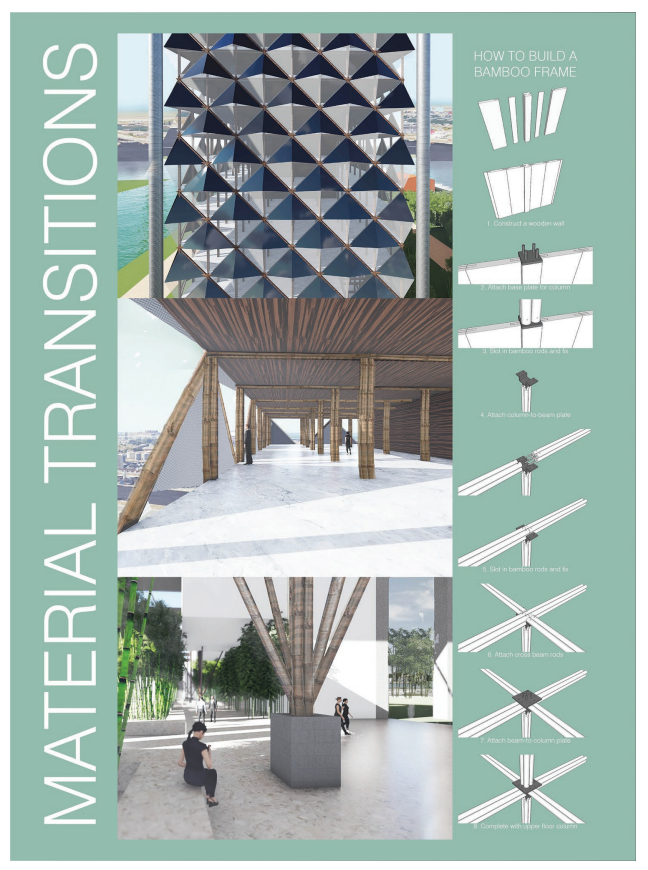

FIGURE 15.8 Gemma Galeno, proposal for a bamboo-based post-oil system for Dunkirk, Beyond Oil Studio Spring 2018.

in its soil. Dunkirk and other port cities are not only historical hubs of the petroleumscape but must play a key role in transforming it.

Throughout the petroleum era, corporate actors-often very large ones-have shaped local territories in collaboration with national and local actors, leaving spatial and representational traces that have tied regions such as Dunkirk to petroleum. This long tradition has created path dependencies as defined in the political sciences. Such path development is self-reinforcing, in part because the "embeddedness" of new decisions in already established dynamics implies significant costs to changing strategy. ${ }^{47}$ In making complicated decisions, it is often easier to rely on familiar, proven strategies. Paths thus follow an immanent logic ${ }^{48}$ that make course changes more difficult. Such path development is self-reinforcing, in part because the "embeddedness" of new decisions in already established dynamics implies significant costs to changing strategy. ${ }^{49}$ Path dependence theory emphasizes the role of critical junctures in institution formation, particularly as moments which privilege some pathways over others. The closure of the Dunkirk refinery can be such a critical juncture.

In northwest European port cities, the closure of refineries and ultimately most of the oil-related infrastructure is not a question anymore; time is the only unknown factor. Local authorities of ports must anticipate this outcome and plan for a post-oil future. To achieve such conversion, the EU supports an increasing number of local actors through programs, funding, rules, and policies that support sustainable development and energy transition. The European Green Deal of the new European Commission, which offers a wide range of climate policies and environmental measures, is a first step toward achieving a carbon-neutral Europe by $2050 .{ }^{50}$ As key economic and industrial facilities for the EU's competitiveness, port cities must be at the forefront of the "effective and fair transition" that the commission supports. 
These objectives and the effects of the 2020 COVID-19 pandemic on prices of oil barrels have pushed European oil companies to rethink their strategies, both to protect the environment and their survival. ${ }^{51}$ This unique context must incite all public and private actors to acknowledge and address the petroleumscape and to design the post-oil future in port cities.

\section{Notes}

1 AGUR Dunkerque, "La Toile industrielle ® Schéma des relations inter industrielles du Dunkerquois," http://www.agur-dunkerque.org/publications/publication45, accessed June 12, 2020.

2 M. F. “Total. La 'Toile Industrielle' Endommagée,” L'Humanité, April 16, 2010. https://www. humanite.fr/node/436604, accessed June 12, 2020; "France's Dunkirk Lng Terminal Receives First Cargo," Offshore Energy (July 11, 2016), https://www.offshore-energy.biz/frances-dunkirklng-terminal-receives-first-cargo/, accessed June 12, 2020.

3 "Société de la raffinerie de Dunkerque: un pas de plus vers la fermeture définitive de l'usine," La Voix $d u$ Nord (April 6, 2016). http://www.lavoixdunord.fr/archive/recup\%3A\%252 Fregion\%252Fsociete-de-la-raffinerie-de-dunkerque-un-pas-de-plus-ia17b47588n3430564, accessed June 10, 2020; Total, "Oleum," https://www.oleum.total.com/en, accessed June 10, 2020.

4 Carola Hein, "Oil Spaces: The Global Petroleumscape in the Rotterdam/The Hague Area," Journal of Urban History 44, no. 5 (September 2018): 887-929, DOI:10.1177/0096144217752460.

5 R. J. Forbes, More Studies in Early Petroleum History 1860-1880 (Leiden: E. J. Brill, 1959).

6 Ernst \& Young, The Oil Downstream: Vertically Challenged? (Ernst \& Young, 2012), 2, petroleumclub. ro/downloads/links/The_oil_downstream_vertically_challenged.pdf, accessed September 4, 2018; Carola Hein, “'Old Refineries Rarely Die': Port City Refineries as Key Nodes in the Global Petroleumscape," Canadian Journal of History 53, no. 3 (2018): 450-79.

7 Chambre de Commerce de Dunkerque, "Port de Dunkerque, Exposition universelle de 1878: Recueil des notices etc. produits à l'exposition spéciale des ports de commerce," Bulletin de la Société de géographie commerciale de Bordeaux, no. 5 (March 8, 1884): 134; Plan de Dunkerque et des environs avec indication des nouveaux travaux en cours d'exécution ou en projet, dressé par DURAND, conducteur spécial des waeteringues et Delamare, graveur, 1864 (Paris : imprimerie Janson). See Henri Durin, Dunkerque sous le Second Empire in Dunkerque à travers les siècles, Vol. 2, 1899.

8 Marcel Amphoux, "Une nouvelle industrie française: le raffinage du pétrole," Annales de géographie 44, no. 251 (1935): 509-33.

9 Géo Risques, "Fiche détaillée Basias," http://fiches-risques.brgm.fr/georisques/basias-detaillee/ NPC5909510, accessed June 10, 2020.

10 “Dunkerque. Incendie De L'usine a Petrole De Coudekerque-Branche." L'Illustration, no. 2519 (June 6, 1891).

11 Hein, "'Old Refineries', 450-79.

12 Michael Stephen Smith, The Emergence of Modern Business Enterprise in France, 1800-1930 (Cambridge, MA: Harvard University Press, 2006).

13 Michel Bruguière, Administration et contrôle de l'économie, 1800-1914 (Paris: Librairie Droz, 1985), 23.

14 Amphoux, "Une nouvelle industrie," 509-33.

15 Pierre Fontaine, "Pierre Fontaine. L'Aventure du pétrole français," Les Sept Couleurs (1967): 30.

16 Le Capitaliste, Journal de la banque parisienne, no. 12 (March 20, 1913): 196.

17 Jonathan D. Smele, Historical Dictionary of the Russian Civil Wars, 1916-1926 (Lanham, MD: Rowman \& Littlefield, 2015), 678

18 "Le trait d'union," Société Française des Pétroles BP, no. 43 (Noël 1958): 57.

19 Recueil des procès-verbaux des séances de la Chambre de Commerce, 1909, 430-31.

20 Gabriel Chalandon, "La Politique Francaise Du Petrole," La Revue hebdomadaire, no. 15 (1937); Smith, Modern Business.

21 Recueil des procès-verbaux des séances de la Chambre de Commerce, 1920, XXXI.

22 Paix-Lesieur signed the agreement with the participation of the SNO, the Société Estrine et Cie, and the Banque de La Seine. 
23 Amphoux, "Une nouvelle industrie," 509-33.

24 Alexander Melamid, "Geographical Distribution of Petroleum Refining Capacities: A Study of the European Refining Program," Economic Geography 31, no. 2 (1955): 168-78.

25 Amphoux, "Une nouvelle industrie," 509-33.

26 Total, "Total, a Pioneering Spirit," http://www.total.com/en/our-group/thumbnail/totalleading-energy-operator-almost-century, accessed June 10, 2020.

27 Dubessy, "Colas met en vente sa raffinerie de Dunkerque," Econostrum, January 15, 2016. https://www.econostrum.info/Colas-met-en-vente-sa-raffinerie-de-Dunkerque_a21330.html, accessed 15 January, 2021.

28 André Maurois, J. Blancard, J. Huré, and X. Normand, "La société générale des huiles de pétrole BP présente sa nouvelle raffinerie de Dunkerque 1952," Société Générale des Huiles de Pétrole BP, 1952.

29 Ibid.

30 Ibid.

31 Ibid.; Le trait d'union de la Société Générale des Huiles de Pétrole, no. 18 (December 26, 1952).

32 Stephan Hauser, "The Interplay of Economic Development and Environmental Protection: Dunkirk and the Search for Balance," PORTUSplus 8 (November, 2019), https://portusplus.org/ index.php/pp/article/view/176.

33 Organe de la technique française des travaux publics et du ciment armé, "Travaux," Editions Science et Industrie, 1960.

34 Fabien Guggemos, E. Misak, and D. Mombel, "Importations, exportations, facture énergétique", in Panorama énergies-climat, edited by Ministère de l'Environnement, de l'Énergie et de la Mer, 2016. https://www.ecologie.gouv.fr/sites/default/files/dgec_panorama_energie_climat_16.pdf.

35 Dominique Lejeune, La France des trente glorieuses: 1945-1974 (Paris: Armand Colin, 2015).

36 Joseph, Yvon. "Ports Maritimes", in the opinions presented to the French Senate, Tome VI Equipment et logement, on the 19 November, 1970. https://www.senat.fr/rap/1970-1971/ i1970_1971_0056_06.pdf.

37 Total. "Total Announces Plan to Repurpose its Dunkirk Refinery Site," March 8, 2010. http://www.total.com/en/media/news/press-releases/total-annonce-le-projet-de-mutationindustrielle-de-son-etablissement-de-dunkerque, last accessed September 15, 2017.

38 Caroline Britz, "Interview: Stéphane Raison, Président du Directoire du port de Dunkerque," Mer et Marine, July 7, 2015, accessed 22 February, 2019. https://www.meretmarine.com/fr/ content/interview-stephane-raison-president-du-directoire-du-port-de-dunkerque.

39 British Petroleum, "BP Statistical Review of World Energy 2017," BP Statistical Review of World Energy, June 2017; Saudi Aramco, "Saudi Aramco and Total Launch Engineering Studies to Build Giant Petrochemical Complex in Jubail," October 8, 2018, https://www.saudiaramco.com/ en/news-media/news/2018/saudi-aramco-and-total-launch-engineering-studies-to-buildgiant-petrochemical-complex-in-jubail.

40 Carola Hein, "How the Fourth Industrial Revolution Will Change the Energy Landscape," The Beam, no. 4 (August 17, 2017).

41 Dunkerque Port, "Conserver la biodiversité sur le territoire portuaire de Dunkerque-port," Grand Port Maritime de Dunkerque, 2010, http://www.dunkerque-port.fr/publicmedia/ original/131/25/fr/Dunkerque-Port_Conserver_Biodiversite.pdf, accessed June 26, 2020.

42 ESPO award 2016, https://www.espo.be/news/bremenports-wins-espo-award-2016.

43 Stephan J. Hauser, "Long Live the Heritage of Petroleum-Discoveries of Former Oil Sites in the Port City of Dunkirk," Urban Science 4, no. 2 (2020): 22.

44 The course was developed by Carola Hein, who co-taught it with Henri van Bennekom, with the assistance of Paolo De Martino.

45 Hein, "How the Fourth Industrial Revolution Will Change"; Carola Hein and Paolo De Martino, "Designing Post-Carbon Dunkirk with the Students from Tu Delft," The Beam, no.5 (February 26,2018$)$.

46 Almut Reichel, Mieke De Schoenmakere, J. Gillabel, Jeroen Martin, and Ybele Hoogeveen, "Circular Economy in Europe: Developing the Knowledge Base," European Environment Agency, 2016, https://eco.nomia.pt/contents/documentacao/thal16002enn-002.pdf.

47 Scott E. Page, "Path Dependence," Quarterly Journal of Political Science 1 (2006): 87-115. 
48 The German sociologists Helmuth Berking and Martina Löw introduced the term "Eigenlogik" in 2005, focusing on the peculiarities and unique selling points of cities. Helmuth Berking and Martina Löw, Die Eigenlogik der Städte. Neue Wege für die Stadtforschung (Frankfurt am Main: Campus 2005).

49 Page, "Path Dependence."

50 European Commission, "COM(2019) 640: The European Green Deal," December 11, 2019, accessed January 16, 2020, https://ec.europa.eu/info/sites/info/files/european-greendeal-communication_en.pdf.

51 R. Bousso and Shadia Nasralla, "Coronavirus Widens Climate Rift between European and U.S. Oil Majors," Reuters (May 18, 2020). 